\title{
Aceclofenac topical dosage forms: In vitro and in vivo characterization
}

KAMAL DUA ${ }^{1, *}$

KAVITA PABREJA ${ }^{2}$

MALIPEDDI VENKATA RAMANA ${ }^{3}$

1 Department of Pharmaceutical Technology, School of Pharmacy and Allied Health Sciences

International Medical University Bukit Jalil, Kuala Lumpur

Malaysia-57000

2 Department of Life Sciences School of Pharmacy and Allied Health Sciences, International Medical University Kuala Lumpur, Malaysia-57000

${ }^{3}$ VIT University, Vellore Tamilnadu-632014, India
Aceclofenac is a new generation non-steroidal anti-inflammatory drug showing effective anti-inflammatory and analgesic properties. It is available in the form of tablets of $100 \mathrm{mg}$. Importance of aceclofenac as a NSAID has inspired development of topical dosage forms. This mode of administration may help avoid typical side effects associated with oral administration of NSAIDs, which have led to its withdrawal. Furthermore, aceclofenac topical dosage forms can be used as a supplement to oral therapy for better treatment of conditions such as arthritis. Ointments, creams, and gels containing $1 \%(\mathrm{~m} / \mathrm{m})$ aceclofenac have been prepared. They were tested for physical appearance, $\mathrm{pH}$, spreadability, extrudability, drug content uniformity, in vitro diffusion and in vitro permeation. Gels prepared using Carbopol $940\left(\mathrm{AF}_{2}, \mathrm{AF}_{3}\right)$ and macrogol bases $\left(\mathrm{AF}_{7}\right)$ were selected after the analysis of the results. They were evaluated for acute skin irritancy, anti-inflammatory and analgesic effects using the carrageenan-induced thermal hyperalgesia and paw edema method. $\mathrm{AF}_{2}$ was shown to be significantly $(p<0.05)$ more effective in inhibiting hyperalgesia associated with inflammation, compared to $\mathrm{AF}_{3}$ and $\mathrm{AF}_{7}$. Hence, $\mathrm{AF}_{2}$ may be suggested as an alternative to oral preparations.

Keywords: aceclofenac, topical gel, in vitro activity, in vivo activity

In recent times, topical drug delivery systems have gained on importance for local and sustained action of many therapeutic agents. Topical application of drugs offers potential advantages of delivering the drug directly to the site of action and acting for an extended period of time (1). However, few studies on topical gel formulations reported the therapeutic effects of drugs in a variety of experimental inflammation and inflammatory pain conditions.

Aceclofenac is available in the form of 100-mg tablets for oral use. Importance of aceclofenac as a new generation NSAID has inspired development of topical dosage

\footnotetext{
*Correspondence; e-mail: kamalpharmacist@gmail.com,kamal_dua@imu.edu.my
} 
forms. This mode of administration may help avoid typical side effects associated with oral administration of NSAIDs such as gastric irritation, particularly diarrhea, nausea, abdominal pain and flatulence. Furthermore, it can be used as a supplement to oral therapy for better treatment of conditions such as arthritis. Hence, the aim of the present work was to prepare topical formulations of aceclofenac using various dermatological bases and to determine percutaneous absorption of the active ingredient.

\section{EXPERIMENTAL}

\section{Materials}

Aceclofenac (AF) was obtained as a gift sample from Ipca Laboratories (India). Carbopol, PEGs, HPMC 940 bee wax, cetostearyl alcohol, methyl paraben, propyl paraben and white soft paraffin were purchased from B-Pura Labs (India). Carrageenan was purchased from Sigma Chemicals (USA). Other chemicals used were of analytical reagent grade.

\section{Preparation of semisolid dosage forms}

Various semisolid formulations of aceclofenac were prepared according to the compositions given in Table I using different dermatological bases $\left(\mathrm{AF}_{1}-\mathrm{AF}_{4}\right.$ with Carbopol gel base, $\mathrm{AF}_{5}$ with paraffin base; $\mathrm{AF} 6$ with $\mathrm{HPMC}$ gel base; $\mathrm{AF}_{7}$ with macrogol gel and $\mathrm{AF}_{8}$ with emulsifying ointment base) and applying standard procedures. In each of the formulations, AF was incorporated into the base at a concentration of $1 \%(\mathrm{~m} / \mathrm{m})$. Trituration using the geometric dilution procedure was used to obtain a homogeneous mass.

Carbopol gels. - Carbopol 940 was sprinkled slowly into a small quantity of distilled water and continuously stirred to get a uniform dispersion. To this dispersion, a weighed quantity of pre-dissolved methyl paraben and propyl paraben was added in $5 \mathrm{~mL}$ of water. This preparation was kept overnight so that Carbopol became uniform in texture and appearance and the air bubbles could escape. When the temperature of the base was about room temperature, AF was added to develop the respective formulation by the levigation method.

Hydroxypropylmethylcellulose gels. - A weighed quantity of hydroxypropylmethylcellulose (HPMC) powder was dispersed and hydrated in a portion of hot water (about $1 / 3$ of total volume), heated above $90{ }^{\circ} \mathrm{C}$ with vigorous stirring to prevent lumping and the resultant dispersion was cooled. Methyl paraben, propyl paraben and AF were dispersed in another portion of cold water. This dispersion was added to the HPMC dispersion to achieve complete solubilization of HPMC. The resultant solution was mixed thoroughly with trituration.

Macrogol gel (polyethylene glycol) base. - A weighed quantity of PEG 4000 was melted. To this melt, PEG 400 was added under continuous stirring. The melt was removed from the heating source and the stirring was continued until the melt started congealing. AF was incorporated into the base at room temperature by the levigation method. 
Table I. Composition of topical formulations of aceclofenac

\begin{tabular}{|c|c|c|c|c|c|c|c|c|}
\hline \multirow{2}{*}{ Ingredient } & \multicolumn{8}{|c|}{ Mass } \\
\hline & $\mathrm{AF}_{1}$ & $\mathrm{AF}_{2}$ & $\mathrm{AF}_{3}$ & $\mathrm{AF}_{4}$ & $\mathrm{AF}_{5}$ & $\mathrm{AF}_{6}$ & $\mathrm{AF}_{7}$ & $\mathrm{AF}_{8}$ \\
\hline Aceclofenac & 1.0 & 1.0 & 1.0 & 1.0 & 1.0 & 1.0 & 1.0 & 1.0 \\
\hline Cetostearyl alcohol & & & & & 5.0 & & & \\
\hline Emulsifying wax & & & & & & & & 30.0 \\
\hline Carbopol 940 & 2.0 & 2.0 & 2.0 & 2.0 & & & & \\
\hline Triethanolamine & q.s. & q.s. & q.s. & q.s. & & & & \\
\hline $\mathrm{DMF}$ & & & 30.0 & & & & & \\
\hline Ethanol & & 30.0 & & & & & & \\
\hline Methyl paraben & 0.15 & 0.15 & 0.15 & 0.15 & & 0.2 & & \\
\hline Propyl paraben & 0.05 & 0.05 & 0.05 & 0.05 & & 0.12 & & \\
\hline Hard paraffin & & & & & 3.0 & & & \\
\hline HPMC & & & & & & 20.0 & & \\
\hline PEG 4000 & & & & & & & 50.0 & \\
\hline PEG 400 & & & & & & & 49.0 & \\
\hline DMSO & & & & 30.0 & & & & \\
\hline Mineral oil & & & & & & & & 19.0 \\
\hline White petrolatum & & & & & 89.0 & & & 50.0 \\
\hline White bee wax & & & & & 2.0 & & & \\
\hline Water q.s. & 100 & 100 & 100 & 100 & & 100 & & \\
\hline
\end{tabular}

DMF - dimethyl formamide, DMSO - dimethyl sulfoxide, HPMC - hydroxypropylmethylcellulose, PEG polyethylene glycol.

Simple ointment base. - A weighed quantity of hard paraffin, bee wax, cetostearyl alcohol and white soft paraffin were taken and melted together. The melt was removed from the heating source and the stirring was continued until the melt started congealing. When the temperature of the base reached room temperature, AF was incorporated by the levigation method.

\section{Characterization of semisolid formulations}

Physical appearance. - The physical appearance of formulations was checked visually (color, consistency and texture) while greasiness was assessed by application into the skin surface.

Drug content. - The formulation (200 mg) was transferred into a 100-mL volumetric flask and dissolved in acetic acid $(20 \%, V / V)$. Volume was made up to $100-\mathrm{mL}$, filtered and $1 \mathrm{~mL}$ of this filtrate was transferred into a $10-\mathrm{mL}$ volumetric flask and the volume 
was made up. The absorbance of the resulting solution was recorded using a UV-visible spectrophotometer (Jasco, V-530, Japan) at $275 \mathrm{~nm}$ and the drug concentration was calculated using the respective regression equations.

$\mathrm{pH}$. - About $20 \mathrm{~g}$ of the semisolid formulation was subjected to $\mathrm{pH}$ measurement using a digital $\mathrm{pH}$ meter within $24 \mathrm{~h}$ of manufacture.

Texture profile/rheological studies. - The formulations were evaluated for apparent viscosity, spreadability and extrudability. Apparent viscosity was recorded using a Brookfield synchroelectric viscometer (Scientific International, New Delhi) at $2.5 \mathrm{rpm}$.

About $500 \mathrm{mg}$ of the test formulation was sandwiched between two slides, of $6 \times 2$ $\mathrm{cm}$ each. The lower slide was fixed on the board of the apparatus and the upper slide was tied to a non-flexible string to which 20 -g load was applied with the help of a simple pulley. The time taken for the upper slide to travel the distance of $6 \mathrm{~cm}$ and separate from the lower slide under the influence of weight was noted. Spreadability was calculated using with the following equation (2):

$$
\text { spreadability }=\frac{w \cdot l}{t}
$$

where, $w$ is the weight tied to the upper slide $(20 \mathrm{~g}), l$ is the length of the glass slide (6 $\mathrm{cm})$ and $t$ is the time in seconds.

Extrudability of the formulation was determined using an extrudability apparatus in terms of mass in grams required to extrude a $0.5 \mathrm{~cm}$ ribbon of the formulation in 10 seconds. The average extrusion pressure was noted (3).

Fourier transformed infrared spectroscopy. - Interaction studies were conducted using FTIR (Shimadzu FTIR-8400S, Japan) and IR absorption spectra were taken for the pure drug, freshly prepared and six-month old formulations using the potassium bromide disc method to check any interactions between the formulation components.

In vitro studies. - In vitro diffusion studies for all formulations were carried out using a Keshary-Chein $(\mathrm{KC})$ type diffusion cell $(4,5)$. The diffusion cell apparatus was fabricated locally as an open-ended cylindrical tube with a $3.7994 \mathrm{~cm}^{2}$ area and $100 \mathrm{~mm}$ height, having a diffusion area of $3.8 \mathrm{~cm}^{2}$. Twenty percent $(V / V)$ acetic acid was used as receptor medium. A weighed quantity of the formulation equivalent to $25 \mathrm{mg}$ of the drug was placed onto the dialysis membrane-70 (Himedia Laboratories Ltd., India) and was immersed slightly in $20 \mathrm{~mL}$ of receptor medium which was continuously stirred and maintained at $37 \pm 1{ }^{\circ} \mathrm{C}$. Aliquots of $2.0 \mathrm{~mL}$ were withdrawn at specific time intervals up to $6 \mathrm{~h}$. From the withdrawn aliquot, $1.0 \mathrm{~mL}$ was transferred into a 100-mL volumetric flask, suitably diluted and the AF content was estimated spectrophotometrically. Average of three determinations was used to calculate the cumulative percent drug release at each time point.

In vitro skin permeation studies were carried out for the best three formulations that exhibited higher drug release through the dialysis membrane-70 $(4,5)$ using rat abdominal skin. Rat skin was obtained from the abdominal portion of an albino rat after sacrificing the animal. The hair and fat were removed after treating the skin with $0.32 \mathrm{~mol}$ 
$\mathrm{L}^{-1}$ ammonia solution for 30 minutes. The skin was tied to the $\mathrm{KC}$ diffusion cell (donor cell) so that the stratum corneum side of the skin was in intimate contact with the release surface of the formulation in the donor cell. All experiments were carried out in triplicate.

Kinetic analysis of release and skin permeability data. - The release and skin permeability data of the best three semisolid formulations were subjected to kinetic analysis to establish the drug release mechanism. The release data were fitted to the zero-order, first-order and matrix (Higuchi model) equations $(6,7)$.

Skin irritation test. - The draize patch test was used on rabbits to evaluate the irritation potential of the selected topical formulations. White New Zealand rabbits of either sex $(2.75 \pm 0.25 \mathrm{~kg}, 8-9$ weeks) were supplied by Singhla Scientific suppliers, Ambala, In$\mathrm{dia}$, and were housed individually in the animal house with food and water given ad libitum (8).

Rabbits were divided into three groups $(n=3)$ : group $1-$ no application (control), group 2 - placebo semisolid topical base without AF, and group 3 - formulation treated. The back of the rabbits was clipped free of hair $24 \mathrm{~h}$ prior to the formulation application. The formulation, $0.5 \mathrm{~g}$, was applied on the hair-free skin of rabbits by uniform spreading over an area of $4 \mathrm{~cm}^{2}$. The skin surface was observed for any visible change such as erythema (redness) after 24,48 and $72 \mathrm{~h}$ of the formulation application. The mean erythemal scores were recorded depending on the degree of erythema: no erythema $=0$, slight erythema (barely perceptible - light pink) $=1$, moderate erythema (dark pink) $=2$, moderate to severe erythema (light red) $=3$, and severe erythema (extreme redness) $=4(8)$.

Analgesic and anti-inflammatory activity. - Analgesic and anti-inflammatory activites of selected formulations were evaluated using male Wistar rats (210 \pm 10 g, 6-8 weeks) by carrageenan-induced thermal hyperalgesia using the procedure described by Padi $e t$ al. (9) and the paw edema method using a mercury plethysmograph as described by Winter et al. (10), respectively. For this purpose, rats were divided into four groups $(n=6)$ : group 1 - control (no treatment), group $2-\mathrm{AF}_{2}$ treated, group $3-\mathrm{AF}_{3}$ treated and group $4-\mathrm{AF}_{7}$ treated. They were housed individually with food and water given ad libitum.

\section{Statistical analysis}

Data pertaining to analgesic and anti-inflammatory activities were expressed as mean \pm SD and were analyzed by the one-way analysis of variance (ANOVA) followed by the post hoc Tukey test for multiple comparisons using the Jandel Sigma Stat statistical software, version 2.0.

\section{RESULTS AND DISCUSSION}

All AF formulations were white in color. Carbopol gels $\mathrm{AF}_{1}-\mathrm{AF}_{4}$ appeared to be translucent and glossy while all other formulations were opaque and greasy on application. All the formulations were found to be smooth, free from grittiness and non-greasy on application. 
The drug concentration in dermatological bases was found to range from 0.89-0.95 $\%$ (Table II). This proved that the method adopted was suitable for the preparation of topical dosage forms. As indicated by the value of the drug content, there was no degradation of the drug during the preparation process. As indicated in Table II, the $\mathrm{pH}$ of the formulations ranged from 6.89 to 7.27 , which may be suitable for topical application without any discomfort.

Apparent viscosity ranged from $10.1-35.3 \mathrm{kPa} \mathrm{s}$, spreadability 0.321 to $0.421 \mathrm{~g} \mathrm{~m} \mathrm{~s}^{-1}$ and extrudability 505.23-584.43 g (Table II).

Table II. Physicochemical properties of semisolid formulations containing aceclofenac

\begin{tabular}{cccccc}
\hline Formulation & $\begin{array}{c}\text { Drug loading } \\
(\%, \mathrm{~m} / \mathrm{m})\end{array}$ & $\mathrm{pH}^{\mathrm{a}}$ & $\begin{array}{c}\text { Spreadibility } \\
\left(\mathrm{kg} \mathrm{s}^{-1}\right)^{\mathrm{a}}\end{array}$ & $\begin{array}{c}\text { Extrudability } \\
(\mathrm{g})^{\mathrm{a}}\end{array}$ & $\begin{array}{c}\text { Apparent viscosity } \\
(\mathrm{kPa} \mathrm{s})^{\mathrm{a}}\end{array}$ \\
\hline $\mathrm{AF}_{1}$ & $0.95 \pm 0.02$ & $7.17 \pm 0.03$ & $0.33 \pm 0.01$ & $505.23 \pm 2.09$ & $11.5 \pm 0.6$ \\
$\mathrm{AF}_{2}$ & $0.94 \pm 0.07$ & $7.19 \pm 0.04$ & $0.32 \pm 0.02$ & $531.12 \pm 2.18$ & $10.1 \pm 0.3$ \\
$\mathrm{AF}_{3}$ & $0.95 \pm 0.06$ & $7.01 \pm 0.01$ & $0.35 \pm 0.02$ & $543.18 \pm 2.31$ & $11.7 \pm 0.5$ \\
$\mathrm{AF}_{4}$ & $0.93 \pm 0.04$ & $6.90 \pm 0.02$ & $0.42 \pm 0.01$ & $567.21 \pm 2.45$ & $25.1 \pm 0.8$ \\
$\mathrm{AF}_{5}$ & $0.89 \pm 0.02$ & $7.09 \pm 0.01$ & $0.37 \pm 0.03$ & $542.09 \pm 2.11$ & $20.6 \pm 0.7$ \\
$\mathrm{AF}_{6}$ & $0.91 \pm 0.07$ & $7.27 \pm 0.03$ & $0.39 \pm 0.02$ & $584.43 \pm 2.24$ & $35.3 \pm 0.6$ \\
$\mathrm{AF}_{7}$ & $0.90 \pm 0.04$ & $6.89 \pm 0.04$ & $0.40 \pm 0.04$ & $551.35 \pm 1.99$ & $20.8 \pm 0.5$ \\
$\mathrm{AF}_{8}$ & $0.90 \pm 0.05$ & $6.97 \pm 0.05$ & $0.38 \pm 0.01$ & $532.25 \pm 2.21$ & $15.1 \pm 0.5$ \\
\hline
\end{tabular}

a Mean $\pm \mathrm{SD}, n=3$.

\section{FTIR}

Interactions between the ingredients used in topical formulations, such as AF, Carbopol, HPMC and PEG were studied using FTIR spectroscopy. As indicated by Table III and Fig. 1, AF was identified by the presence of characteristic bands. The FT-IR spectral analysis of aceclofenac alone (Fig. 1a) showed that principal peaks were observed at wave numbers 3340 (N-H stretching vibration for amine), 3100 (carbonyl O-H stretching), 3050 (aromatic C-H stretching), 1730 (carbonyl C=O stretching). The same peaks were observed at 3325, 3115, 3042, 1700, 1520, 1260 and $720 \mathrm{~cm}^{-1}$ in $\mathrm{AF}_{2}$ at 3340, 3095, 3010, 1775, 1580, 1210 and 780 in $\mathrm{AF}_{3}$ at 3355, 3100, 3080, 1710, 1595, 1260, 710 in $\mathrm{AF}_{7}$. All the principal characteristic bands of the drug were also observed in the respective formulations. The findings were suggestive of the absence of any major incompatibility between AF and the components employed in the preparation of dermatological bases.

\section{In vitro diffusion and skin permeability studies}

The drug diffusion pattern from semisolid formulations $\mathrm{AF}\left(\mathrm{AF}_{1}-\mathrm{AF}_{8}\right)$ is presented in Fig. 2a). In vitro diffusion and permeation were found to be better for Carbopol gel formulations $\left(\mathrm{AF}_{2}\right)$ compared to the formulations containing various other dermatological bases. The effect of dermatological base on the drug release profile has been well 
a)

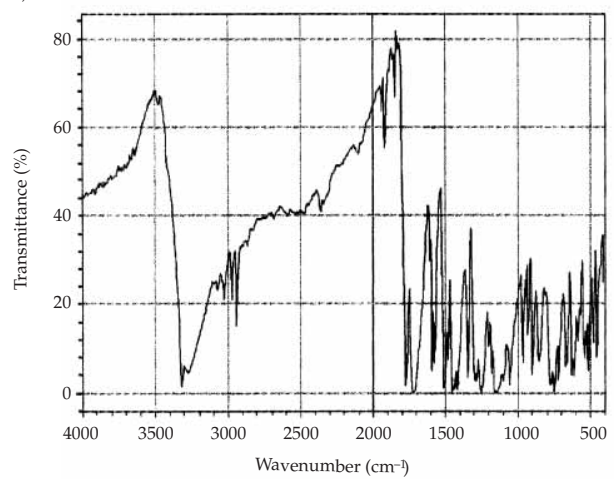

c)

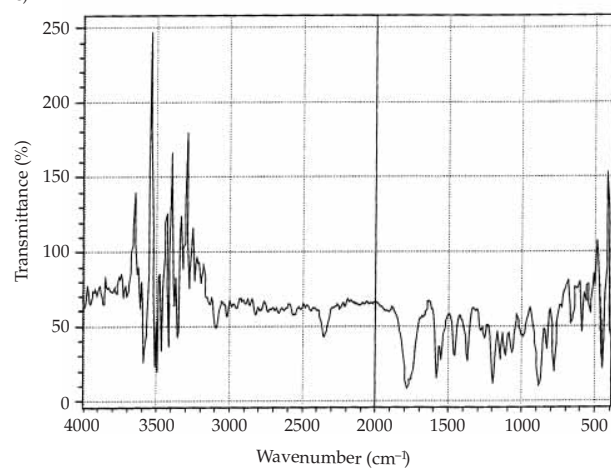

b)

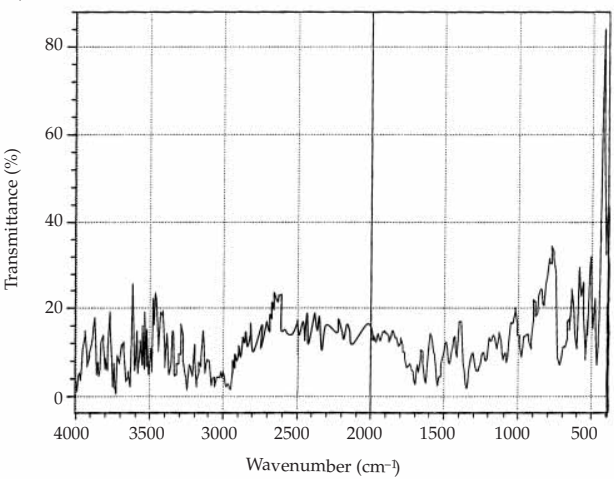

d)

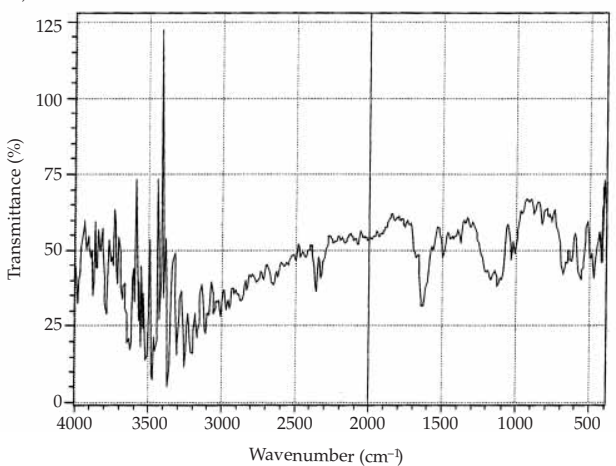

Fig. 1. FTIR spectra of: a) AF, b) AF-Carbopol formulation $\left(\mathrm{AF}_{2}\right)$, c) AF-HPMC formulation $\left(\mathrm{AF}_{6}\right)$, d) AF-PEG formulation $\left(\mathrm{AF}_{7}\right)$.

documented $(11,12)$. Cumulative drug diffusion after $6 \mathrm{~h}$ was $88.2 \pm 2.4 \%$ for $\mathrm{AF}_{2}$, and the cumulative drug permeation within the same time interval was $17.3 \pm 0.8 \%$. Enhanced drug diffusion and drug permeation from the Carbopol gel base may be attributed to the presence of pores in the gel and lack of over-solubilization of the lipophilic drug in the aqueous vehicle, resulting in relatively free diffusion of the drug to the vehicle and hence leading to faster release (13).

Owing to the biphasic nature of creams and various oleaginous bases, partitioning of the drug occurs in aqueous and oil phases, which results in the slower drug release. In case of gels, drug diffusion occurs through the aqueous phase and hence provides a greater drug diffusion and release. The hydroalcoholic Carbopol gel formulation, $\mathrm{AF}_{2}$, showed maximum drug release and permeation profile compared to other hydrogels $\left(\mathrm{AF}_{1}, \mathrm{AF}_{3}\right.$ and $\left.\mathrm{AF}_{4}\right)$, which may be ascribed to the presence of ethanol. Ethanol increases the permeation of drugs through the skin either by attacking the dense barrier structure of the skin (14) or by augmenting the solubility and partitioning of the drug in stratum corneum (15). Furthermore, it decreases the viscosity of Carbopol gel, which leads to improved drug diffusion and permeation from the gel. The effect of ethanol in in vitro dif- 

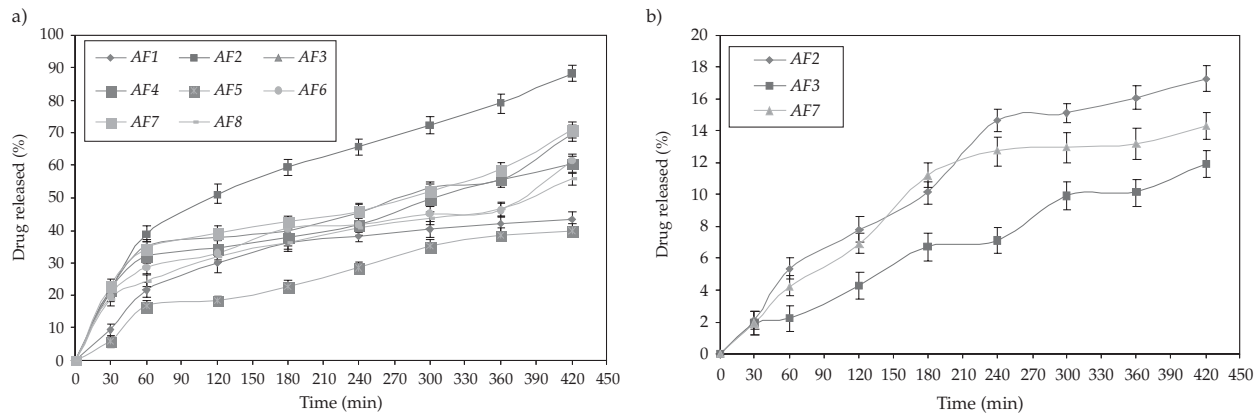

Fig. 2. In vitro a) diffusion profile of aceclofenac semisolid formulations $\left.A F_{1}-A F_{8}, b\right)$ skin permeation profile of $\mathrm{AF}_{2}, \mathrm{AF}_{3}$ and $\mathrm{AF}_{7}$. Mean $\pm \mathrm{SD}, n=3$.

fusion and permeation is in agreement with previous investigations on ketoprofen gel formulation, which was attributed to decreased viscosity and increased solubility of the drug in the gel (16).

The extent of in vitro permeation of the drug through the skin after $6 \mathrm{~h}$ was in the range $11.9 \pm 0.8 \%$ to $17.3 \pm 0.8 \%$ for aceclofenac formulations (Fig. $2 b$ ). The extent of permeation of the drug is not sufficient to exert a systemic action but it is sufficient enough to exert a local action at the site of application. This inadequate permeation through the skin is possibly due to the strong affinity of the hydrophobic drug to the lipophilic stratum corneum or the barrier effect of the latter despite the use of permeation enhancers. However, the diffusion of AF from the three selected formulations was in the same order as that from the dialysis membrane.

The in vitro diffusion and in vitro skin permeation data of the best three formulations of aceclofenac $\left(\mathrm{AF}_{2}, \mathrm{AF}_{3}\right.$ and $\left.\mathrm{AF}_{7}\right)$ were subjected to kinetic analysis. The selection criteria $\left(R^{2}\right)$ and the equations best describing the kinetics of in vitro drug release and in vitro skin permeation are given in Table III. The release of the drug from all formulations was found to follow the first-order release kinetics. The results are in agreement with the previous investigation performed by Rafiee and Mehramizi (17). Higher correlation, as indicated by $R^{2}$, was observed for the Higuchi matrix release kinetics in all the selected formulations, suggesting diffusion as a probable prominent mechanism of drug release. In diffusion, the rate of drug dissolution within the matrix must be much higher than that of the diffusion rate of the drug leaving the matrix.

Table III. Kinetic models applied on the in vitro diffusion of selected semisolid formulations

\begin{tabular}{ccccccc}
\hline \multirow{2}{*}{ Formulation } & \multicolumn{2}{c}{ Zero-order } & \multicolumn{2}{c}{ First-order } & \multicolumn{2}{c}{ Higuchi } \\
\cline { 2 - 7 } & $R^{2}$ & $k_{0}\left(\% \mathrm{~h}^{-1}\right)$ & $R^{2}$ & $k_{1}\left(\% \mathrm{~h}^{-1}\right)$ & $R^{2}$ & $k_{\mathrm{H}}\left(\% \mathrm{~h}^{-1 / 2}\right)$ \\
\hline $\mathrm{AF}_{2}$ & 0.9386 & 1.31 & 0.9469 & 0.057 & 0.9711 & 7.29 \\
$\mathrm{AF}_{3}$ & 0.9775 & 1.85 & 0.9801 & 0.032 & 0.9548 & 6.42 \\
$\mathrm{AF}_{7}$ & 0.8838 & 2.50 & 0.8912 & 0.029 & 0.9551 & 8.23 \\
\hline
\end{tabular}

$k_{0}$ - zero-order rate constant, $k_{1}$ - first-order rate constant, $k_{\mathrm{H}}-$ Higuchi rate constant 
The point-to-point correlation between in vitro diffusion data and in vitro skin permeation data of selected semisolid formulations was established by regression analysis. Among the three selected formulations, the correlation of $\mathrm{AF}_{2}$ was found to be superior $\left(R^{2}=0.9536\right)$ compared to $\mathrm{AF}_{3}\left(R^{2}=0.8787\right)$ and $\mathrm{AF}_{7}\left(R^{2}=0.8522\right)$.

\section{Skin irritation}

Placebo and the selected $\mathrm{AF}$ formulations $\left(\mathrm{AF}_{2}, \mathrm{AF}_{3}, \mathrm{AF}_{7}\right)$ were devoid of any irritation potential and no edema formation was observed in any case. Irritation score (primary skin irritation index) for all the formulations was zero, which indicated its safety and acceptability for topical administration.

\section{Analgesic and anti-inflammatory activity}

Carrageenan administration into the rat hind paw produced a significant inflammation associated with hyperalgesia, as shown by decreased rat paw withdrawal latency in response to a thermal stimulus $\left(47 \pm 0.5{ }^{\circ} \mathrm{C}\right) 4 \mathrm{~h}$ after carrageenan injection.

All the selected $\mathrm{AF}$ formulations $\left(\mathrm{AF}_{2}, \mathrm{AF}_{3}, \mathrm{AF}_{7}\right)$ showed time-dependent inhibition of carrageenan-induced thermal hyperalgesia (Table IV). In contrast, topical application of $\mathrm{AF}_{2}$ significantly attenuated the development of hypersensitivity to thermal stimulus as compared to the control $(p<0.05)$ and other formulation treated groups $(p<0.05)$.

Subcutaneous administration of carrageenan into the hind paw produced significant edema, with a maximum response being observed $5 \mathrm{~h}$ after injection. All the selected AF semisolid formulations, when applied topically $2 \mathrm{~h}$ before carrageenan administration, inhibited paw edema in a time-dependent manner (Table V) with maximum

Table IV. Effect of selected aceclofenac semisolid formulations on paw withdrawal latency to thermal stimuli in rats

\begin{tabular}{ccccc}
\hline \multirow{2}{*}{ Time (min) } & \multicolumn{4}{c}{ Paw withdrawal latency $(\mathrm{s})^{\mathrm{a}}$} \\
\cline { 2 - 5 } & Control & $\mathrm{AF}_{2}$ & $\mathrm{AF}_{3}$ & $\mathrm{AF}_{7}$ \\
\hline 0 & $8.58 \pm 0.34$ & $8.66 \pm 0.38$ & $8.62 \pm 0.36$ & $8.63 \pm 0.37$ \\
30 & $7.01 \pm 0.42$ & $7.28 \pm 0.48$ & $7.61 \pm 0.43$ & $7.48 \pm 0.39$ \\
60 & $6.75 \pm 0.42$ & $6.80 \pm 0.46$ & $6.41 \pm 0.36$ & $6.77 \pm 0.36$ \\
90 & $6.05 \pm 0.34$ & $6.88 \pm 0.46$ & $6.11 \pm 0.45$ & $6.30 \pm 0.40$ \\
120 & $4.25 \pm 0.62$ & $6.50 \pm 0.39^{\mathrm{b}}$ & $5.91 \pm 0.40$ & $6.06 \pm 0.33^{\mathrm{d}}$ \\
150 & $3.86 \pm 0.55$ & $7.48 \pm 0.35^{\mathrm{b}}$ & $6.20 \pm 0.33^{\mathrm{c}}$ & $6.52 \pm 0.32^{\mathrm{d}}$ \\
180 & $3.69 \pm 0.48$ & $7.99 \pm 0.31^{\mathrm{b}}$ & $6.90 \pm 0.41^{\mathrm{c}}$ & $6.69 \pm 0.31^{\mathrm{d}}$ \\
240 & $3.52 \pm 0.36$ & $7.90 \pm 0.38^{\mathrm{b}}$ & $7.10 \pm 0.32^{\mathrm{c}}$ & $7.51 \pm 0.37^{\mathrm{d}}$ \\
\hline
\end{tabular}

a Mean $\pm \mathrm{SD}, n=6$.

Statistically significant difference, $p<0.05$ : ${ }^{\mathrm{b}} \mathrm{AF}_{2}$ vs. control, ${ }^{\mathrm{c}} \mathrm{AF}_{2}$ vs. $\mathrm{AF}_{3}, \mathrm{~d}^{\mathrm{d}} \mathrm{AF}_{2}$ vs. $\mathrm{AF}_{7}$ 
Table $V$. Effect of selected aceclofenac semisolid formulations on paw edema in rats

\begin{tabular}{cccc}
\hline \multirow{2}{*}{ Time (h) } & \multicolumn{3}{c}{ Edema inhibition (\%) ${ }^{\mathrm{a}}$} \\
\cline { 2 - 4 } & $\mathrm{AF}_{2}$ & $\mathrm{AF}_{3}$ & \multicolumn{1}{c}{$\mathrm{AF}_{7}$} \\
\hline 0 & $10.53 \pm 2.43^{\mathrm{b}, \mathrm{c}}$ & $15.79 \pm 2.56^{\mathrm{c}}$ & $5.26 \pm 2.34$ \\
1 & $32.14 \pm 3.87^{\mathrm{c}}$ & $28.57 \pm 4.12$ & $25.00 \pm 4.65$ \\
2 & $54.05 \pm 4.21^{\mathrm{b}, \mathrm{c}}$ & $40.54 \pm 4.56$ & $45.95 \pm 4.12$ \\
3 & $68.89 \pm 2.43^{\mathrm{b}, \mathrm{c}}$ & $53.33 \pm 2.67^{\mathrm{c}}$ & $60.00 \pm 2.34$ \\
4 & $75.00 \pm 4.34^{\mathrm{b}, \mathrm{c}}$ & $59.62 \pm 4.87$ & $63.46 \pm 4.47$ \\
5 & $80.33 \pm 2.52^{\mathrm{b}, \mathrm{c}}$ & $67.21 \pm 2.96$ & $70.49 \pm 2.45$ \\
\hline
\end{tabular}

a Mean $\pm \mathrm{SD}, n=6$.

Statistically significant difference, $p<0.05:{ }^{\mathrm{b}} \mathrm{AF}_{2}$ vs. $\mathrm{AF}_{3},{ }^{\mathrm{c}} \mathrm{AF}_{2}$ vs. $\mathrm{AF}_{7}$.

edema inhibition of $80.3 \pm 2.5 \%$ achieved with $\mathrm{AF}_{2}$ after $5 \mathrm{~h}$ of carrageenan administration. However, topical application of $\mathrm{AF}_{2}$ significantly prevented the development of edema compared to formulations $\mathrm{AF}_{3}$ and $\mathrm{AF}_{7}(p<0.05)$.

\section{CONCLUSIONS}

Topical route of application has a great potential as an effective and safe way to administer aceclofenac for local analgesic effect. The in vitro diffusion demonstrated good correlation with the in vitro skin permeation. Among all the semisolid formulations, Carbopol gel base was found to be the most suitable dermatological base for aceclofenac semisolid formulation with maximum release of the.

Acknowledgments. - The authors are grateful to Ipca Laboratories, Mumbai, India, for their generous gift sample of aceclofenac. The authors also express their thanks to the U.P. Technical University, Lucknow, India, for their valuable support.

\section{REFERENCES}

1. Y. G. Bachhav and V. B. Patravale, Formulation and evaluation of meloxicam gels, Acta Pharm. 60 (2010) 153-163; DOI: 10.2478/v10007-010-0020-0.

2. Y. G. Bachhav and V. B. Patravale, Microemulsion based vaginal gel of fluconazole: Formulation, in vitro and in vivo evaluation, Int. J Pharm. 365 (2009) 175-179; DOI: 10.1016/j.ijpharm. 2008.08.021.

3. C. M. Chakole, M. A. Shende and S. N. Khadatkar, Formulation and evaluation of novel combined halobetasol propionate and fusidic acid ointment, Int. J. Chem. Tech. Res. 1 (2009) 103-116.

4. V. Rajni and P. R. P. Verma, Diffusion study of ibuprofen from ointment base, Ind. J. Pharm. Sci. 57 (1995) 1-6. 
5. A. Mohammed, S. Yasmin and A. Asgar, Transdermal delivery of $\beta$-blockers, Exp. Opin. Drug Del. 3 (2006) 405-418; Acta. Pharm. 53 (2003) 119-125; DOI: 10.1517/17425247.3.3.405.

6. T. Higuchi, Mechanism of sustained action medication, theoretical analysis of rate of release of solid drugs dispersed in solid matrices, J. Pharm. Sci. 52 (1963) 1145-1149; DOI: 10.1002/jps. 2600521210

7. P. Costa and J. M. Sousa Lobo, Modeling and comparison of dissolution profiles, Eur. J. Pharm. Sci. 13 (2001) 123-133; DOI: 10.1016/S0928-0987(01)00095-1.

8. B. J. Vermeer, Skin irritation and sensitization, J. Control. Rel. 15 (1991) 261-265; DOI: 10.1016/ 0168-3659(91)90117-V.

9. S. Padi, N. K. Jain, S. Singh and S. K. Kulkarni, Effect of selective inhibition of cyclooxygenase-2 on lipopolysaccharide-induced hyperalgesia, Inflammopharmacol. 12 (2004) 57-68; DOI: 10.1163/ 156856004773121374.

10. C. A. Winter, E. A. Risley and G. W. Nuss, Carrageenan-induced oedema in hind paw of the rat as an assay for anti-inflammatory drugs, Proc. Soc. Exp. Biol. Med. 111 (1962) 544-547.

11. J. Aukunuru, C. Bonepally and V. Guduri, Preparation, characterization and optimization of ibuprofen ointment intended for topical and systemic delivery, Trop. J. Pharm. Res. 6 (2007) 855-860.

12. Z. Gürol, S. Hekimo Lu, R. Demirdamar and M. Umnu, Percutaneous absorption of ketoprofen. I. In vitro release and percutaneous absorption of ketoprofen from different ointment bases, Pharm. Acta Helv. 71 (1996) 205-212; DOI: 10.1016/0031-6865(96)00011-8.

13. V. V. Dhavse and P. D. Amin, Formulation and evaluation of topical bases of ketoprofen, East Pharm. 40 (1997) 133-135.

14. Y. Obata, K. Takayama, Y. Maitano, Y. Machida and T. Nagai, Effect of ethanol on the permeation of ionized and non-ionized diclofenac, Int. J. Pharm. 89 (1993) 191-198; DOI: 10.1016/0378-5173(93)90243-9.

15. W. A. C. Megraban and B. W. Barry, Oestradiol permeation across human skin, silastic and snake skin membrane: the effect of ethanol:water cosolvent system, Int. J. Pharm. 116 (1995) 101-112; DOI: 10.1016/0378-5173(94)00321-U.

16. S. C. Chi and H. W. Jun, Release rate of ketoprofen from poloxamer gel in a membraneless diffusion cell, J. Pharm. Sci. 80 (1991) 280-283; DOI: 10.1002/jps.2600800318.

17. T. M. Rafiee and A. Mehramizi, In vitro release studies of piroxicam from oil-in-water creams and hydroalcoholic gel topical formulations, Drug Dev. Ind. Pharm. 26 (2000) 409-414; DOI: $10.1159 / 000085864$.

\section{Dozirani pripravci aceklofenaka za topičku primjenu: In vitro i in vivo karakterizacija}

KAMAL DUA, KAVITA PABREJA i MALIPEDDI VENKATA RAMANA

Aceklofenak je lijek nove generacije nesteroidnih protuupalnih lijekova sa izraženim protuupalnim i analgetskim djelovanjem. Dostupan je u obliku tableta od $100 \mathrm{mg}$. U ovom radu razvijeni su dozirani pripravci za topičku primjenu u svrhu smanjenja ili uklanjanja nuspojava povezanih s oralnom primjenom nesteroidnih protuupalnih lijekova. Ti pripravci mogu se upotrijebiti kao dodatak peroralnoj terapiji artritisa i srodnih bolesti. Opisana je priprava mazila, krema i gela s $1 \% \mathrm{~m} / \mathrm{m}$ aceklofenaka te njihova fizička 
svojstva, pH, mazivost, istiskivost, jednolikost sadržaja ljekovite tvari, difuzija i permeabilnost in vitro. Nakon analize rezultata za daljnja ispitivanja odabrani su gelovi pripravljeni na bazi Carbopola $940\left(\mathrm{AF}_{2}, \mathrm{AF}_{3}\right)$ i makrogola $\left(\mathrm{AF}_{7}\right)$. Ispitana je akutna iritacija kože, protuupalno i analgetsko djelovanje koristeći karagenom induciranu termičku hiperalgeziju i edem šape. Pripravak $\mathrm{AF}_{2}$ bio je značajno $(p<0,05)$ učinkovitiji u inhibiciji hiperalgezije s upalom nego pripravci $\mathrm{AF}_{3}$ i $\mathrm{AF}_{7}$. Stoga se $\mathrm{AF}_{2}$ može predložiti kao alternativa peroralnim pripravcima.

Ključne riječi: aceklofenak, topički gel, aktivnost in vitro, aktivnost in vivo

Department of Pharmaceutical Technology, School of Pharmacy and Allied Health Sciences, International Medical University, Bukit Jalil, Kuala Lumpur, Malaysia-57000

VIT University, Vellore, Tamilnadu-632014, India 